\title{
Miscalculations of the military strategy of the United States and its NATO allies to "democratize" Afghanistan
}

\author{
Sh. SHUKUROV 1 \\ Military Academy General Staff of the Russian Armed Forces
}

\begin{tabular}{l} 
ARTICLE INFO \\
\hline Article history: \\
Received June 2021 \\
Received in revised form \\
20 June 2021 \\
Accepted 15 July 2021 \\
Available online \\
15 August 2021 \\
\\
\hline Keywords: \\
The Afghan Ministry of \\
Defense, \\
American troops from \\
Afghanistan, \\
Joe Biden administration, \\
NATO Secretary General \\
Jens Stoltenberg, \\
"Afghanistan Study Group", \\
international radical groups, \\
US strategy, \\
Andrey Serenko.
\end{tabular}

ABSTRACT

The Afghan conflict, which has lasted for more than three decades, at the turn of 2011-2012 went through a new cycle of its evolution. In June 2011, it was announced that the withdrawal from countries of American troops and at the same time - about the start of direct US talks with the Taliban. Observers agreed that the complete conclusion US troops in 2014 will not end conflict, but can contribute to its new round. Few assumed that in the mid-1970s began one of the longest-running and most internationalized modern regional conflicts. By its complexity it is comparable to the situation on the Korean Peninsula and the Middle East conflict. It is noteworthy that none of external participants in the Afghan situation could not completely turn off, even with the withdrawal of troops, Afghanistan gave rise to and showed the limits for many international endeavors.

2181-1415/C) 2021 in Science LLC.

This is an open access article under the Attribution 4.0 International (CC BY 4.0) license (https://creativecommons.org/licenses/by/4.0/deed.ru)

\section{AQSHning harbiy strategiyasi va NATO ittifoqchilari Afg'onistonni "demokratlashtirish" bo'yicha noto'g'ri hisob-kitoblari}

\footnotetext{
Kalit so'zlar:

Afg'oniston Mudofaa vazirligi,

Afg'onistondagi Amerika qo'shinlari,

Jo Bayden ma'muriyati, NATO Bosh kotibi Yens Stoltenberg,
}

\section{ANNOTATSIYA}

O'ttiz yildan oshiq davom etgan afg'on mojarosi 20112012-yillar oxirida o'z evolyutsiyasining yangi tsiklidan o'tdi. 2011-yil iyun oyida Amerika qo'shinlarining mamlakatdan chiqarilishi va shu bilan birga - AQShning Tolibon bilan to'g'ridan-to'g'ri muzokaralari boshlanishi haqida e'lon qilindi. Kuzatuvchilar AQSh qo'shinlarining 2014-yildagi to'liq xulosasi mojaroni tugatmaydi, balki uning yangi bosqichiga o'z hissasini qo'shishi mumkin, degan fikrga kelishdi. 70-yillarning o'rtalarida

\footnotetext{
${ }^{1}$ Lieutenant Colonel, Adjunct of the Military Academy of the General Staff of the Armed Forces of the Russian Federation, Moscow, Russia.

Email: zayniyev.temur@bk.ru.
} 
"Afg'onistonni o'rganish guruhi", xalqaro radikal guruhlar, AQSh strategiyasi, Andrey Serenko. eng uzoq davom etadigan va xalqaro miqyosdagi zamonaviy mintaqaviy to'qnashuvlardan biri boshlangan deb o'ylaydiganlar kam. Murakkabligi bilan uni Koreya yarim orolidagi vaziyat va Yaqin Sharqdagi mojaro bilan solishtirish mumkin. Shunisi e'tiborga loyiqki, Afg'oniston vaziyatining tashqi ishtirokchilarining hech biri to'liq o'chira olmadi, hatto qo'shinlar olib ketilsa ham, Afg'oniston ko'plab xalqaro urinishlarning chegaralarini ko'rsatdi.

\section{Просчеты военной стратегии США и их союзников по НАТО на «демократизацию» Афганистана}

\section{Ключевые слова:}

Министерство обороны

Афганистана,

американские войска в

Афганистане,

администрация

Джо Байдена,

генеральный секретарь

НАТО Йенс Столтенберг,

«Группа изучения

Афганистана»,

международные

радикальные

группировки,

стратегия США,

Андрей Серенко.

\section{АННОТАЦИЯ}

Афганский конфликт, длившийся более трех десятилетий, на рубеже 2011-2012 годов прошел новый цикл своего развития. В июне 2011 года было объявлено о выводе из страны американских войск и одновременно - о начале прямых переговоров США с талибами. Наблюдатели сошлись во мнении, что полное завершение войск США в 2014 году не положит конец конфликту, но может способствовать его новому витку. Мало кто предполагал, что в середине 1970-х начался один из самых продолжительных и интернационализированных современных региональных конфликтов. По своей сложности она сопоставима с ситуацией на Корейском полуострове и ближневосточным конфликтом. Примечательно, что ни один из внешних участников афганской ситуации не смог полностью отключить, даже с выводом войск, Афганистан породил и показал пределы для многих международных усилий.

The United States has already withdrawn a third of its forces from Afghanistan. This was reported by the Central Command of the country.

"According to US Central Command estimates, we have completed 30 to $44 \%$ of the entire withdrawal process", the agency said in a statement. The Central Committee clarified that about 300 cargo planes with materials were removed from Afghanistan, and 13 thousand pieces of equipment for disposal were transferred to the Logistics Agency of the Ministry of Defense. In addition, the United States has officially transferred six facilities to the Afghan Ministry of Defense.

World The United States withdrew a third of the contingent from Afghanistan The United States has already withdrawn a third of its military contingent from Afghanistan. This was reported by the Central Command of the country. "According to US Central Command estimates, we have completed 30 to $44 \%$ of the total the withdrawal process, "the ministry said in a statement. The Central Committee clarified that about 300 cargo planes with materials were removed from Afghanistan, and 13 thousand pieces of equipment for disposal were transferred to the Logistics Agency of the Ministry of Defense. In addition, the United States has officially transferred six facilities to the Afghan Ministry of Defense. Advertising on Gazeta.uz In mid-April, US President Joe Biden announced the 
withdrawal of American troops from Afghanistan. The process is planned will complete by 9/11 - the 20th anniversary of the terrorist attacks in New York.

The Wall Street Journal previously wrote that the United States is considering options for deploying troops and military equipment withdrawn from Afghanistan in Central Asia or the Middle East. In mid-May, President of Uzbekistan Shavkat Mirziyoyev noted the importance of efforts to maintain peace in Afghanistan, given the withdrawal of US troops. "What will life be like thanks to our efforts after the withdrawal of US troops and their NATO allies? - asked Shavkat Mirziyoyev. - If other states think about it, being far away, for us it is a neighbor. If, God forbid, any conflict breaks out on the other side of the bridge, how will this affect all our efforts made? With this in mind, we must work daily to keep the peace. We must always be ready for the most difficult conditions, and if we can be ready, we will never lose", he stressed.

After the Joe Biden administration came to power in the United States, NATO is changing its strategy in Afghanistan. How will this change affect the TAPI project, the republics of Central Asia, and what does Pakistan have to do with it? NATO Secretary General Jens Stoltenberg on February 4 demanded that the Taliban break with al-Qaeda and end the violence. On the same day, the "Afghanistan Study Group", created at the initiative of the US Congress, proposed the new American administration to urgently resume negotiations with the Taliban on postponing the withdrawal of US troops from Afghanistan. The day before, on February 3, German Foreign Minister Heiko Maas voiced the position of Germany: the withdrawal of NATO troops from Afghanistan depends on progress in the inter-Afghan negotiations, and is not tied to a specific date.

And the NATO press service clarified that until the beginning of May there will be no reduction in the military contingent in Afghanistan - and this is about 10 thousand people - there will be no reduction. Joe Biden's Afghan strategy and the Heiko Mas formula All of this indicates that the United States and NATO intend to abandon Donald Trump's plan to withdraw US troops from Afghanistan by early May 2021. According to the agreement reached earlier by his special envoy for Afghanistan Zalmay Khalilzad with representatives of the Taliban in Doha, after that peace talks were to begin with the official government in Kabul. The Taliban interpreted the February news as a refusal of the West from an agreement with them and announced that they would continue their armed struggle against foreign occupation.

Andrei Serenko, an employee of the Center for the Study of Modern Afghanistan (CISA), explains that the formula voiced by Heiko Maas, most likely, will be the essence of the US strategy under Joe Biden. "If earlier the withdrawal of troops was first supposed, and then the Taliban entered into negotiations with official Kabul, now, first, the Taliban are invited to agree on peace with the government, and only then the withdrawal of NATO troops will begin", he says. According to the expert, this change in strategy decisively affects the approach countries of Central Asia towards settlement in a neighboring state.

Central Asia after the change of the negotiating paradigm with the Taliban In recent years, all the republics of the region, with varying degrees of intensity, have been building their relations with the Taliban. "Ashgabat offered its own negotiating platform, but under the auspices of the UN. Tashkent conducted its negotiations with the Taliban and tried to help Kabul and the Taliban come to terms", recalls Taalatbe, the former director of the UN special political mission in Afghanistan to Masadykov. 
The countries of Central Asia, based on their own security interests, want stabilization in Afghanistan: there are training camps and commanders of several international radical groups who dream of overthrowing secular governments in all these countries. In addition, the Taliban are hindering the implementation of large economic projects, be it the TAPI gas pipeline or the railway from Uzbekistan through Afghanistan to Pakistan to the Indian Ocean.

TAPI without the Taliban

"It is unlikely that these projects will be feasible until the conflict in Afghanistan is resolved”, Masadykov says. However, in his assessment, NATO's decision itself not to rush to withdraw from Afghanistan does not contribute to this settlement.

"Large states too often act in Afghanistan depending on their own political calendar, and not in the name of solving its internal problems. It is important for the countries of the region that Afghanistan does not boil, that there are no terrorist groups there. But the very presence of NATO has long been a trigger of unrest: some groups receive weapons from foreigners, some - money, intelligence games are being played, proxy wars between groups loyal to certain external participants, and so on further", - explains the interlocutor DW.

Andrey Serenko assesses the situation differently. The negotiation process with the Taliban is an illusion; they are not going to share power with anyone in Afghanistan and intend to take it by force in order to build a state according to the model of an Islamic emirate. "It is unlikely that the countries of the region would be delighted with this project. Now they need to again be more oriented towards NATO, the role of which will increase, as well as the role of the United States", says the TsISA expert. As for transport projects with the participation of Afghanistan, they cannot be solved without the Taliban, he agrees. "But even with the Trump agreement with the Taliban, I did not see the best prospects for these projects, since the civil war in Afghanistan was not annulled by this agreement", Andrei Serenko emphasizes. Central Asia in search of stability and the role of Pakistan "And in Dushanbe, and in Nur-Sultan, and in Tashkent, and Ashgabat, and in Bishkek, they will breathe a sigh of relief when they learn that the United States will not suddenly leave Afghanistan. Contacts in these capitals with the Taliban will remain - just in case. But there they understand that if something really needs to be negotiated with the Taliban, then for this it is necessary to go to Islamabad, to the command of the army and intelligence, which are now Taliban operators", explains the TsISA expert.

The special services of Uzbekistan, Kyrgyzstan, Tajikistan, and Turkmenistan have stable contacts with colleagues in Pakistan. "Islamabad is interested in activity in Central Asia, including for countering Indian projects and attempts by Indian special services to build their communications in the region. But I still don't see any progress beyond these contacts", says DW's interlocutor. According to him, this is due to the fact that Pakistan is now facing an economic collapse.

During the last months, there have been the offices of the Bank of Pakistan were closed, including the largest representative office in Ashgabat, through which the financing of the TAPI project went. "In this context, the revision of the US strategy is a bad sign for Islamabad. We are talking about the possible introduction of economic sanctions by the US, so that Pakistan would more intensively contribute to" forcing the Taliban "to peace", says Serenko. On the one hand, sanctions can induce the Taliban to be more compliant, but, 
on the other hand, they can reduce the possibilities of Islamabad on participation in major projects related to Central Asia.

\section{REFERENCES:}

1. Mirziyoyev Sh.M. We will build our great future together with our brave and noble people. - T.: "O'zbekiston", 2017. - P. 488.

2. Mirziyoyev Sh.M. Address of the President of the Republic of Uzbekistan Shavkat Mirziyoyev to the Oliy Majlis. -T: "Uzbekistan” NMIU, 2018. - P. 88.

3. Mirziyoyev Sh.M. Critical analysis, strict discipline and personal responsibility should be the daily rule of every leader. - T.: "O'zbekiston", 2017. - P. 104.

4. Mirziyoyev Sh.M. Together we will build a free and prosperous, democratic state of Uzbekistan. - T.: "O'zbekiston", 2017. - P. 32.

5. Mirziyoyev Sh.M. The rule of law and the protection of human interests are the key to the country's development and the well-being of its people. - T.: "O'zbekiston", 2017. - P. 48.

6. My pain is Afghanistan: a collection of documentary essays and memoirs of internationalist soldiers. - Krasnoyarsk: book. Publishing house, 1989. - P. 133.

7. Verstakov V. Afghan Diary / Victor Verstakov. - M.: Military Publishing, 1983. - P. 141.

8. Sinelnikov G. Afghanistan. Pain. Memory / Gennady Sinelnikov. - Abakan: Khak Publishing House. State UN - them. N.F. Katanova, 1999. - P. 404.

9. Soldiers of the World: Works on the Modern Army. - M.: Sov. Russia, 1985. S. 380-414.

10. Tamonikov A.A. Mountain attack / Alexander Tamonikov. - M.: Eksmo, 2014. P. 352. - (I have the honor. The best novels about Russian officers).

11. Dynin I.M. After Afghanistan: "Afghans" in letters, documents, eyewitness accounts / I.M. Dynin. - M.: Profizdat, 1990. - P. 144. 